\section{Royal Society asks for more}

THE Royal Society, the premier British scientific society, is to be given a hefty nudge towards the popularization of science, to judge by a meeting on the under the auspices of the British Association for the Advancement of Science in London on Monday.

The meeting was convened by Sir Hans Kornberg, British Association president, to provide a debating forum for the Royal Society ad hoc committee on public chestnuts were brought out on Monday and re-roasted, Dr Walter Bodmer, chairman of the Royal Society committee, used the occasion to demonstrate his committee's determination that its work would not gather dust on any shelf.

The need is certainly great. In Britain, on the whole, there is little sign of a scientific lobby, nor of any determined effort by the universities or research councils to educate or even entertain the public in science. Bodmer and his committee wish this situation to change, and by starting at the Royal Society, traditionally a somewhat austere institution whose motto is "nullus in verba" (nothing in words) they are certainly taking the bull by the horns. Dr Bodmer hoped the Royal could provide a lead which others could follow. "public understanding of science" held understanding. And while many old

During Monday's meeting, Dr Bodmer, director of the Imperial Cancer Research Fund, received support from many quarters both in the media and in government. Sir Robin Nicholson, chief scientist in the Cabinet Office, claimed it is now almost impossible to find a political issue without scientific or technical content, and that "90 per cent of his time" is used in advising government on these matters (and only 10 per cent on science itself). Science and technology are now central to many foreign policy issues, said Sir Robin, in the way that international trade took centre stage 25 years ago. But "the attention span grows shorter as one gets older" so now cabinet ministers can only cope with five-minute briefings or three pages of A4. The same is true of leaders of industry. But scientists, for good reasons, are trained to write in extenso and giving equal weight to many ideas. This is completely at odds with what is needed in government, or in the press.

Dr Bodmer was keen to affirm that he would like the Royal to play an active role in getting scientists to approach the media. A member of the science advisory panel to the British Broadcasting Corporation (which, incidentally, reckons it shows four times as many science hours in proportion to output as does US television ), Bodmer is also taking seriously advice to expand the

\section{Animal experimentation}

\section{Alternatives neglected}

\section{Washington}

A STUDY of animal experimentation by the National Academy of Sciences* suggests that institutional barriers within the biomedical community in general and the National Institutes of Health (NIH) in particular may discourage researchers from developing models of human disease and physiology based on non-mammalian organisms. The study, which was commissioned by $\mathrm{NIH}$, does not directly criticize NIH's funding patterns; it does, however, recommend that the agency should support good research "without taxonomic or phylogenetic bias"' and consider directing funds specifically to the development of promising model systems. Harold Morowitz of Yale University, chairman of the study, said there is " anecdotal evidence that it is difficult for people working on unconventional models to get funding'". The natural bias has been in favour of using organisms closest to man, he said; unconventional proposals submitted to NIH for support do not usually fit into the mandate of any of the standard study sections, and are reviewed by ad hoc committees that are not always sympathetic.

Morowitz said that researchers working

*Models for Biomedical Research, National Academy Press, Washington, DC, $1985 \$ 18.50$. in unconventional systems often report that they managed to get started only by "bootlegging" funds from other more conventional research projects.

The study notes that as biological understanding shifts more and more to the molecular level, increasingly the best model for human disease and physiology is not a closely related whole organism that displays a similar macroscopic feature; rather it is often many organisms, each an analogue of a fundamental biological principle inresearch on the human disease myasthenia gravis, a neuromuscular disorder. Six different animal models have been used to discover its cause: an autoimmune attack on acetylcholine receptors at neuromuscular junctions. Studies on chick muscle cells in culture showed that a snake venom binds specifically to these receptors; the venom was then used to demonstrate that patients had a striking shortage of receptors. A cobra neurotoxin that blocks the receptors was administered to rats to see if a shortage of receptors could explain the observed disease symptoms. And to see if an autoimmune response could be involved, rabbits were immunized wth receptor cells isolated from invertebrate species. volved. One example cited in the study is
Royal Society's programme of science briefings, to institute rapid press conferences on scientific issues behind and in the news, to run deeper, background seminars on scientific matters, and to produce detailed condensed briefing documents for journalists.

On a warning from Sir James Gowans, chairman of the Medical Research Council, that such exercises cost money and a lot of time, Dr Bodmer said he hoped the Royal Society would be able to find backing "if not from government" from industry - which should benefit in the long run from better public knowledge. His committee's report is due in a few months' time.

Robert Walgate

\section{Big telescope race}

Washington

OHIO State University and the University of Arizona have decided to raise a total of \$25-30 million for an 8-metre monolithic mirror instrument to be built on Mount Graham in southeastern Arizona. If others can be persuaded to join the project, the telescope may even be equipped with two 8-metre mirrors, which could be combined for optical interferometry.

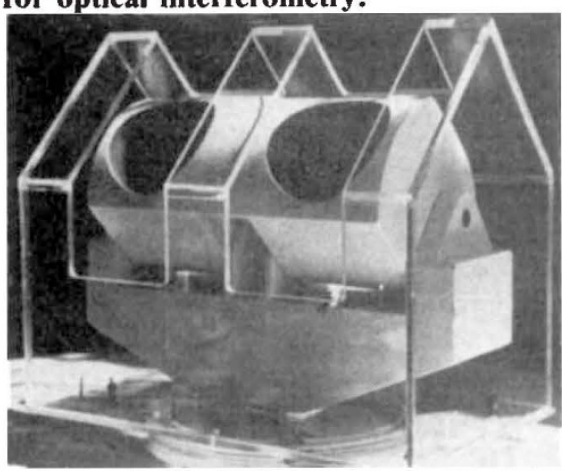

The universities have not yet identified the private sponsors who they hope will supply most of the capital cost of the instrument. Both universities have, however, recently launched large fund-raising efforts, with a target of $\$ 100$ million at Arizona and \$250 million at Ohio. Astronomers at both universities are confident that the money will be found.

The telescope, which would also operate at infrared wavelengths, will have computer links allowing it to be operated remotely from both Arizona and Ohio. The miror or mirrors will be made using a technique developed by Roger Angel at Arizona (see Nature 295, 651; 1982) in which mirrors of honeycomb structure are spun-cast into a parabolic shape. A new computer-actuated lap allows very deep dishes to be polished with a focal ratio of $f 1$, so that telescopes can be built that are much smaller and cheaper than hitherto. A 1.8-metre mirror made recently using the new technique "came out beautifully", according to Dr Angel. Preliminary design work on the new telescope is due to start later this year; construction might take a further four years. Tim Beardsley 